\title{
PLAGUE OF 1900 AND THE ECONOMIC EFFECT ON THE OVERSEAS COMMERCE OF IZMIR
}

\author{
Emine ZEYTINNLі*
}

\begin{abstract}
Domestic economic activities and international commerce of Izmir were severely impaired by the strict quarantine of 1900 adopted against the presence of plague. However, the plague cases were very few, strict quarantine measures imposed. The epidemic and then quarantine left a major impact on the economy of Izmir and conflicts arose between the health commission, local and foreign merchants. All business-related activities such as labour movements, shipping services, foreign trading operations and business meetings suffered. Archival documents report that unemployment soared and scarcity of food started to become a major problem and meetings were organised to protest the situation. This paper aims to analyse the economic effects of the epidemic of 1900 by focusing on the decline in commercial operations and economy. Ottoman archival documents, Ottoman Yearbooks (salname) of Izmir as well as British consular reports are used for that purpose.
\end{abstract}

Keywords: Izmir, plague, quarantine, economic decline, overseas trade.

$\ddot{O} z$

1900 Yılı Veba Salgını ve İzmir'in Dış Ticaretine Etkileri

1900 yılında İzmir'de baş gösteren veba salgını İzmir ve çevresi illerin ekonomik faaliyetlerini ve dış ticaretini olumsuz etkilemiştir. Hükümetin ve yerel otoritelerin ağır karantina tedbirleri aldığ 1 iddia edilen uygulamalardan İzmir ekonomisi olumsuz etkilenmiş, karantina komisyonu ile yerli ve yabancı tüccarların uygulamaların anlaşmazlığa düşmesine neden olmuştur. İş gücü hareketleri, denizcilik hizmetleri ve diş ticaret gibi bütün iktisadi faaliyetler karantina tedbirlerinde olumsuz etkilenmiştir. Osmanlı Arşivi belgeleri karantina sırasında işsizliğin arttı̆̆ını, gıda kıtlığı baş göstermeye başladığını, tedbirler aleyhine toplantılar düzenlendiğini ve halkın valilik binasına yürüdüğünü yazmaktadır. Bu çalışma 1900 yılındaki veba salgını dolayısıyla uygulanan karantina tedbirlerinin İzmir'deki ticari faaliyetlere ve şehir ekonomisine etkisini analiz etmeyi amaçlamaktadır. Çalışma için esas olarak Osmanlı arşiv belgeleri, İzmir Salnameleri ve İzmir'deki Britanya Konsolosluğu Ticaret Raporları kullanılmıştır.

Anahtar Kelimeler: İzmir, veba salgını, karantina, ekonomik zayıflama, dış ticaret

\footnotetext{
* Dr., İstanbul Aydın University, Faculty of Economics and Administrative Sciences, Sefaköyİstanbul. Mail: eminezeytinli@aydin.edu.tr. ORCID: 0000-0003-2515-8819

(Makale Gönderim Tarihi: 10.12.2019 - Makale Kabul Tarihi: 12.02.2020)
} 


\section{Introduction}

Izmir has been a unique and multi-religious seaport city of the Ottoman Empire and over the course of centuries; it grew into a vivid mercantile centre with its superior international port in the Eastern Mediterranean. It has been generating important amount of economic revenue from a number of products such as cotton, silk, carpets, and agricultural products. It was the port integrating the Ottoman Empire into the world economy as well as the centre for Western merchants and their manufactures.

Epidemics, storms and pirate's attacks were three main threats to the coastal cities with severe destructive effects when they hit. The plague had been always the most periodic epidemic with very high rates of death in a short time. It destroyed the societies in terms of severe death, daily practice, population and paralysed the economic activities and foreign trade. Thus, quarantine measures were developed in time and strictly applied when possible.

The plague of 1900 caused temporary destruction to the running of businesses while ensuring the continuation of domestic and international trade was essential for Izmir and the whole region.

The epidemic in Izmir affected the trading activities and merchants claimed that the epidemic was announced to be plague by doctors for the sake of profit and demanded to quarantine to be over.

Due to due to the geographic position, Izmir was exposed to epidemics since they were carried by seamen, traders and the goods from one port to others. Since the bad reputation of the epidemic, when the plague cases were seen in Izmir, Ottoman health and custom authorities immediately started to apply quarantine measures. Uncompromising application of quarantine measures caused temporary destruction to trade and businesses in the city. It also affected the nearby cities in which foreign merchants were doing trade and business.

The official correspondence and commercial statistics clearly show that quarantine measures were taken by the local government created more economic and social problems than the epidemic itself. Due to the quarantine measures the trade decreased, flow of goods stopped, unemployment increased, and the situation created by these factors led to social disorders in the city. Merchants demanded to quarantine to be over for the sake of profit and continuation of their businesses.

This paper attempts to analyses the economic effects of the quarantine which was put in place against the plague epidemic in 1900 in Izmir Province and economic hinterland of it. The study is carried out with the analysis of the correspondences between the governor of Izmir and the central government and Yearbooks of Izmir as well as British Consulate Trade Reports of Izmir. 


\section{Brief Analysis of the Epidemic in the Ottoman Empire and Quarantines}

Diseases and plague played a major role in demography of Ottoman Empire similar to the other countries. Similarly, social and economic impacts were severe; precautions and other preventive measurements had destructive economic effects.

Panzac (2017) made a comparative study on the frequency of plague in Europe and the Ottoman Empire and found out that the time gap between two European cities is much longer than the cities in Ottoman dominions. It was 51 years for Lyon, 54 years for Milan and Venice; 62 years for Barcelona, 70 years for Genova, 71 years for Marseille and 127 years for Napoli. However, the average was much shorter in the East that Ottoman cities were facing severe attacks every 20 to 25 years. On the other hand, in the eighteenth century, the annual mortality rate from a plague in Ottoman port cities such as Salonica and Izmir were found to be the level of Barcelona in the fourteenth century. In other words, desperation against plague in the Eastern Mediterranean in the eighteenth century was the same in Europe in the fourteenth century. ${ }^{1}$

The Ottoman community showed a certain characteristic against certain epidemics such as cholera, plague, typhus, etc., and it was the general interpretation that even the simplest precaution was not taken against it due to the religious faith and fatalism. White (2010) claims European essential conception of the Muslim approach has simplified the response of the Ottoman authorities to diseases, demonstrate that "...Ottoman responses to disease were often more practical and less fatalistic than previously supposed..." ${ }^{2}$ However, by the beginning of the nineteenth century, as a result of European trade partner countries pressure, the central government established a program, namely a new understanding of preventive measures, sanitary improvements and travel restriction against infectious diseases. ${ }^{3}$ Moreover, İzmir was proven to have a superior position of preventive measures, infrastructure and precautions compared with other cities due to the busy maritime activities, activeness of European merchants, Levantine community and local doctors. ${ }^{4}$

\footnotetext{
${ }^{1}$ Panzac, 2017, p. 185-187.

${ }^{2}$ White, 2010, p. 552, 555.

${ }^{3}$ The case of different epidemics and reaction of Muslims, as well as later quarantine against the plague, was under the observation of European travellers. The following statement is on establishing the quarantine measures. "Sultan Mahmud had recently established a strict quarantine against it. This was such an outrage upon Moslem piety that he accompanied his firman with a skillful argument reconciling the measure with Islam..." Hamlin, 1877, p. 303.

${ }^{4}$ Beyru (2005) made a detailed analysis on different epidemics effected life and economy of İzmir of the nineteenth and twentieth centuries. It includes general health condition of the city,
} 
Preventive measures such as establishing a cordon sanitary, maritime quarantine or border crossing control within the country were aimed to be applied for controlling the epidemic. These methods were imposed by local health authorities within the Ottoman Empire through establishing a government body called 'karantinahane'.

\section{Epidemics, Position of Port Cities and Izmir}

Various counties were devastated by plague by the beginning of the twentieth century. The epidemic believed to be originated in China, carried by trading routes and reached to Europe, United States and Australia. ${ }^{5}$

Examining the frequency of the plague historically shows that there is a very close relationship between the economic activity of the port cities where the trade was intense and the occurrence of the plague in these cities was high. ${ }^{6}$ Panzac mentions that Istanbul and Izmir, in two of the five largest ports of the Eastern Mediterranean were under the certain treatment of plague ${ }^{7}$ over the course of centuries and most of the time it arrived at the city via commercial ships and their plague stricken mariners. ${ }^{8}$

Mediterranean with the plague-stricken crews and passengers were a potential danger for every port city and their nearby ones. A travelogue mentions that "The plague is communicated by the commercial communication with other ports in the Levant, and battles every precaution to affect its entire ceadication..."

Natural advantages of Izmir for becoming a trading centre and being existed by commerce were mentioned in various consular trade reports of Izmir, traveler accounts as well as local sources. ${ }^{10}$ Moreover, being well adapted to commercial purposes was considered as another advantage. An English traveler, John Miller in 1829 mentioned that houses of European subjects were built towards the sea, attached with their warehouses and conveniently built for the use of different purposes, particularly in the times of presence of plague when inhabitants were confined to their houses. ${ }^{11}$

epidemics and duration, health conditions and establishments for improving these conditions including medical officials. For a detailed assessment see Beyru, 2005.

${ }^{5}$ For a a detailed assessment on trading routes, maritime trading world, port cities, outbreak and frequency of diseases see Benedict, 1998, McKeough, 2018.

${ }^{6}$ Panzac, 2017, p. 72.

${ }^{7}$ For a detailed assessment on different epidemics of İzmir in the nineteenth and beginning of the twentieth centuries see Beyru, 2005.

${ }^{8}$ Panzac, p. 109-110.

${ }^{9}$ Dallaway, 1797, p. 200.

${ }^{10}$ For a detailed assessment on demographic composition and economic activities see Landau 1985.

${ }^{11}$ John Fuller, 1829, p. 42. 
Izmir was a convenient port for inbounding and out-bounding ships, a potential made it an indispensable centre both for domestic and foreign trade. Agricultural products of interior cities and other commercial commodities such as cotton, silk, yarn that was essential for European exporters as well as western manufactures contributed the mercantilist development of the city and positioned Izmir as the principal port of the Ottoman Empire. ${ }^{12}$ It was again its favourable harbour made it the principal place where chief European factories established and served as the main hub of the region not only for the local manufactures of the region but also accepting domestic and international cargo vessels. ${ }^{13}$ This capacity and busy commercial operations ${ }^{14}$ put it and its hinterland into a severe risk of spread of epidemics and it was infected more often than the other cities and commercial centres. Therefore, the city was one of the "plague ports' 15 of the time.

\section{The Plague of 1900 in Izmir}

Before the spread of the epidemic of 1900 in Izmir, on May $9^{\text {th }}, 1900$, there were some steps and order on establishing quarantine from the Ottoman Palace for a possible plague arriving in Izmir from Egypt and the Suez Canal and around it. ${ }^{16}$ Five days earlier than that time, on May $4{ }^{\text {th }}$, a local newspaper called Ahenk

${ }^{12}$ Izmir played a crucial role in the foreign trade of the Ottoman Empire, its importance and value of trade increased over the course of centuries and contributed to the trade balance of the empire. For example, between 1840 and 1873, the total value of its trade increased fourfold and generated a cumulative surplus. For more information see Kasaba, 1988, pp. 87-106.

${ }^{13}$ The port was exporting domestic output such as food processing, textile; importing European textile, mainly cheap cloths. For a detailed assessment see Parliamentary Papers, 1908, p. 9; Parliamentary Papers, 1910, p. 19.

${ }^{14}$ For the general features of market of İzmir, commercial operations and navigation at İzmir see Issawi, 1980.

${ }^{15}$ For a a detailed assessment on the spread of the epidemic on different continents and devastating demographic, economic and social effects see Echenberg, 2010.

${ }^{16}$ Prime Ministry Archives (hereafter BOA), (Y..EE..KP..,), 11/1038. Moreover, on the report of the Bubonic Plague of 1898-1901, the first person suspected to be plague was reported on the $7^{\text {th }}$ of May, 1900, and this illness has begun on May $3^{\text {rd }}$. Medical authorities and bacteriological investigation confirmed the diagnosis and meanwhile another case was reported. All of them made a good recovery. Parliamentary Papers, 1902, p. 129.

However, the Public Health Report of the United States Sanitary Commissioner from İstanbul reported the first appearance of the bubonic plague in İzmir to be on the May 8, with the registration of 17 cases. Zavitziano1900, p. 2076.

The report on the British Medical Journey based on its correspondence in İstanbul reported the appearance of plague in İzmir to be on May 7 and the last on July 31. The report provided detail information on the number of infected and dead persons, their ethnic background, as well as origin of the epidemic. "...these 22 cases 13 were severe, 5 were of medium severity, and 4 were mild. Nine of the patients died. The Greek community appeared to be the most susceptible to the 


\section{Emine ZEYTINLI}

was reporting a quarantine for the passengers for five days from Port Said and Suez Canal which can be interpreted as precaution. However, that duration of quarantine was increased to ten days on May $7^{\text {th }}$ which was the day of the report of the first suspected person to be plague. ${ }^{17}$ Still, the cypher telegram was ordering the governorship of Izmir to establish quarantine in the city on May $28^{\text {th }}$ which indicates the arrival of plague to the city. ${ }^{18}$

The Ottoman response to this plague seemed to be practical according to the Ottoman archival documents. Local health authorities together with the central government ${ }^{19}$ decided to eliminate person-to-person contact by putting people and cities into quarantine, namely act for infected individuals and then the quarantine was enforced the city itself within the rise in death. These measures prevented the entry of merchant's vessels into the port coming from the Middle East, Mediterranean basin as well as overland vessels for five days.

After the second death from the plague, a committee established in the province of Aydin with the decision of the central government and on June $26^{\text {th }}$, 1900 and this committee decided to increase measures covering three provinces of Aydin, Manisa and Izmir. ${ }^{20}$ The plague resulted in the government to force quarantine for 40 days on the date of June $13^{\text {th }}$, 1900. Social, demographic and

disease, and of 7 patients of this nationality as many as 5 died. The other cases and deaths were distributed as follows: Turks, 7 cases and 2 deaths; Armenians, 3 cases and 1 death; Jews, 4 cases and 1 death; and Catholics, 1 case, which recovered. The large majority of the patients were drawn from the poorer classes of the population. The origin of the plague in Smyrna was never ascertained, but according to the official report of Dr. Lontfi Bey and Dr. Mizzi the infection was almost certainly brought from Egypt, and not by pilgrims returning from the Hedjaz...", Plague and Plague Measures in the Turkish Empire, The British Medical Journal, Vol. 2, No. 2086, 1900, p. 1810.

An Ottoman archival document mentions the beginning of the illness as May $4^{\text {th }}$. For the detailed lists of infected people and if they made a recovery or not, see BOA, Y..PRK.SH. 6/49.

Moreover, the epidemic was mentioned as a possible plague still in a week in an archival document mentioning precautions to be taken for the province of the Archipelago, Cezayir-i Bahr-i Sefid. For a detailed assessment see BOA, DH.MKT., 2345/73.

${ }^{17}$ Ahenk Gazetesi, May 4, May 7, 1900.

${ }^{18} \mathrm{BOA}, Y . . E E . . K P . ., 10 / 1070$.

${ }^{19}$ For a detailed assessment see BOA, Y..PRK.ASK., 162/12, BOA, Y..EE..KP..,11/1079,11/1080.

${ }^{20}$ BOA, Y..PRK.ASK., 162/12. However, United States Sanitary Commissioner reported on May 25, 1900 that "...the sanitary inspector-general, Dr. Cozzonis, was sent to Smyrna in order to make the necessary inquiries and take the direction of the sanitary service. At the same time, the director of the institute pasteur of this town was sent to Smyrna, as well as another microscopist, Dr. Naury. The result of the microscopical examination of the case has been reported to the Ottoman Government by cipher telegram, and at the same time the assurance has been given that there is no fear of spread..." Zavitziano, Examination of Plague Case at Smyrna-Spread of Plague on Turco-Persian Frontier, Public Health Reports (1896-1970), Vol. 15, No. 25, Report No 246, 1900, p. 1613. 
especially economic effects of the plague continued until the beginning of September 1900. An archival document on August $23^{\text {rd }}, 1900$ mentions the abolishing the quarantine and its measures and another document on September the $3^{\text {rd }}, 1900$ mentions the defeat of the plague epidemic in Izmir. ${ }^{21}$

Plague, political approach and economic interests resulted in strong reaction against the plague precautions. ${ }^{22}$ Measures taken by the local health authorities were found extreme and damaging on daily life as well as the economic life of the city. ${ }^{23}$ Local and foreign merchant protested the measures and duration claiming that the epidemic was not severe; the local doctors were forcing unnecessary quarantine in the city in order to have some benefits such as a political order and professional degree as well as benefitting from selling medical equipment. ${ }^{24}$ By the beginning of August 1900, the central government appointed a new commission to examine the epidemic on site in provinces of Izmir and Aydin. ${ }^{25}$ Other trading centres and port cities of the region were also reported to be suffering from the plague and quarantine. ${ }^{26}$

\section{The Effect to the General Economic Condition}

The most important two outcomes of the plague are demographic and economic ${ }^{27}$ impacts that it created irregularity in trade and blocked it for a period.

${ }^{21}$ BOA, Y..A...HUS., 409/98, DH.MKT., 2398/93.

${ }^{22}$ Similar conflict experienced in San Francisco during the epidemic of 1900-1904 which created conflict between business and municipal leaders, the board of supervisors, and health authorities. For a detailed assessment see Philip A. Kalisch, 'The Black Death in Chinatown: Plague and Politics in San Francisco 1900-1904', Arizona and the West, vol. 14, no. 2, 1972, pp. 113-136.

23 "From May to September, 1900, the trade of Smyrna was greatly affected by the sanitary measures adopted in consequence of the occurrence of plague. Quarantine against arrivals from Smyrna were imposed by the other ports of the Ottoman Empire and by some other nations. The results were disastrous to comer and to the working classes, and many debtors made it a pleas for failure to meet their obligations." Parliamentary Papers, Reports and Papers on Bubonic Plague, 1898-1901, p. 130.

${ }^{24}$ BOA, Y..EE..KP.., 11/1039. Despite the claim, prohibiting import from Izmir and forcing the quarantine for 10 days in May by the Greek government shows the significance of the epidemic. For a detailed assessment see BOA, Y..EE..KP.., 11/1038.

${ }^{25}$ BOA, A.MKT.MHM., 566/16.

${ }^{26}$ Vice Consul of Ayvalik (Aivali) reported as "The plague at Smyrna ... considerably affected the tree of Aivali in 1900. Nearly the whole of the province of Aidin was place in quarantine, which put a stop to all commerce, and the excessive freight, consequent on the war was severely felt in the trade with the United Kingdom...", Parliamentary Paper, 1901, p. 12.

${ }^{27}$ Panzac explains the reasons for the spread of the plague epidemic in two reasons that lack of hygiene, its effects and the unavoidable economic value of the plague-infected commercial materials that ships were carrying. However, Panzac referred plague precisely in his work, this statement can go for any other epidemics as they require quarantine. For a detailed assessment see Panzac, 2-17, pp. 93-94. 
Commercial activities in Izmir, hosting chief European factories and accepting domestic and international cargo vessels, surely depressed, profits hurt and therefore restrictions and duration were protested.

On June $13^{\text {th }}$ of 1900 , the governor of Aydin wrote about the general economic condition to the ministry of interior. He informed that general trade activities almost stopped completely due to strict measures taken against the plague. He analysed both sea and land transport and reported that by May 1900 only 79 ships arrived at the port of Izmir while the number reached to 210 ships in the previous year of 1899; transport capacity of Kasaba-Izmir railway line dropped. Its crop and regular product capacity decreased down to 50 percent and passenger to 5 percent, and a situation of Aydin railway to be in the similar position. ${ }^{28}$ It was also reported that economic condition of crop growers got worse day by day along with the porters, watermen and labourers that they could not transfer the crop and sell in the cities which were mainly Izmir. ${ }^{29}$ On June $13^{\text {th }}$ of 1900, the governor of Aydin reports the ministry of health that the duration of quarantine was increased to ten days which earlier was five days. However, the period necessary to purify suspicion of the plague was 4 hours initially before the decision to have it five days. This diplomatic correspondence record that however there were only three people died of the plague, it was already affecting the economic life in Izmir for about 40 days. The letter informs also that the port loaded from eight to nine cargo ships every day regularly, however, since the epidemic, there was no marine traffic in the port. ${ }^{30}$ Therefore, labor dependent on works at the harbour left jobless with severe economic hardship. Trade routes on land were also in the same catastrophic condition that agricultural products could

${ }^{28}$ Another archival document within a month following on the 13th of June 1900, mentioned that 500 passengers travelling to Izmir daily and it dropped to 15 to 20 passengers within the epidemic and this caused a drop in the transport revenues by a quarter. These numbers show the fall in daily economic activities. “...Malumata göre mukaddema yevmiye beş yüz yolcu İzmir'den dahile ve bir o kadar da dahilden İzmir'e yolcu nakil edilmekte olduğu halde nakliyyat-ı yevmiye on beş- yirmi nefere tenzil etmiş ve mahsulat-ı nakliyyatı ise evvelkinin rub'u derecesine inmiştir." BOA, Y..EE..KP.., 11/1079.

${ }^{29}$ Due to earthquake and quarantine and the trade of İzmir was interrupted and a fund rising committee was set up. “...deprem ve karantinalar sebebiyle İzmir'in sekteye uğrayan ticareti nedeniyle geçinemeyen ailelere, oluşturulan özel komisyon aracılığıyla yardım toplandiğından...”, BOA, Y..EE..KP.., 11/1078.

${ }^{30}$ Trade of the city is almost completely interrupted and while there is not any cargo ship being loaded, the number was 8 to 10 . “...umur-ı ticariyye külliyyen sektedar olup bundan evvel yevmi sekiz on vapur emn ü şedd ederek İmir limandan yük alıp yük vermekteler iken bu müddette liman dahilinde hiçbir vapur görülmemektedir..." Y..EE..KP.., 11/1079. Local newspaper Ahenk informs the same economic condition of the city, See Ahenk Gazetesi, June 14, 1900. 
not be transported to the port of Izmir due to quarantine and this caused an economic downturn in the producers' condition of the whole region. ${ }^{31}$

Local and foreign merchant and European countries' consuls also expressed their concerns about extreme measures of local health authorities and the cause of the action to their trading activities. ${ }^{32}$ Therefore, British consuls of Izmir and other trading European countries' agents met the local government and decided to help on the issue. They also visited the governor about the epidemic and stated their support for relaxing the measures in order to boost the market again. ${ }^{33}$

Acting Consul of Britain, Charles S. Hampson, reported the epidemic in his yearly correspondence and mentioned that the plague effected life in general and economic activities from May to September in 1900 as the quarantine law was rigidly observed. He also reported that keeping the city under the comprehensive quarantine system resulted in severe cost on trade. However, the epidemic was not severe, all type of business activities damaged, unemployment increased, maritime activities interrupted and thus export and import from the city decreased in volume. He also reported that the causes effected the export and

${ }^{31}$ Land transportation from Aydin is in the same condition that boatmen, porters and all other workers of İzmir are in needy position. Considering also producers' condition that they cannot transfer their products to Izmir, the quarantine is requested to be limited only with the city of İzmir and this was the practice during the time of cholera. "...Aydin şimendiferinin nakliyatı dahi ayn-ı raddade olup binaen aleyh zalik harekât-ı ticariyye yüzünden İmir'de gitmekte olan binlerce kayıķı hammal ve amele-i saire esbab-ı maişetten mahrum kalarak muhtaç-ı iane oldukları misüllü dahilde ise ahali dahi ahz ve 'ataya dâri olan kisardan? Mahsullerini nakl ve furuht edemeyip binaen aleyh muzayaka-i umumiyye görülen kesb-i şiddet etmekde olduğundan mevzu' olan sihhiyye kordonunun kolera zamaninda olduğu gibi hudud-l vilayete nakliye tevsi ' $i$ umumen arzu ve istid 'a olunmakta...", BOA, Y..EE..KP.., 11/1079.

${ }^{32}$ It has been claimed that European maritime powers such as Great Britain, France, and Holland imposed their own understanding of economic and health measures and precautions. Reforms and preventive measures were considered as a way of justifying these interventions. However, Ottoman officials were bitterly criticised and urged to establish an extensive quarantine regime with the signing of the Commercial Convention of 1838, recent measures in the case of Izmir were found excess due to the duration and very low number of infected individuals. Similarly, countries and authorities try to strengthen the economy and their positions by imposing or increasing measures for the sake of protection. For a detailed assessment see Bulmuş, 2015.

Ahmed Mithat as the chief clerk of the Karantinahane writes that deciding on quarantine was a controversial issue among the commercial rivals as they wanted to depress each other's profits or simply gain more profit. Therefore, implementing preventive measures were possible based on a country's best economic interests. “...muamele-i tahaffuziyye adeta bir rekabet-i ticariyye meydanı olduğundan bazı devletler diğer bazılarının memalikine karşı hiçbir lüzum olmaksızın dahi karantina vaz ederler idi.", Mithat, 1902, p. 458. Shakow (2009) makes a similar analysis and defines adopting a quarantine system as a weapon in trade to be used against competitors. For a detailed analysis see Shakow, 2009.

${ }^{33}$ BOA, Y..EE..KP.., 11/1079. 


\section{Emine ZEYTINLI}

import trade was so unfavorably in 1900 and the account of trade is sufficient to show how seriously the trade of Izmir suffering during that year. The total value of export fell from 3.780.000 Pounds in 1899 to 2.540.000 Pounds in 1900; those to the United Kingdom falling from 2.190.000 Pounds to 1.700.000 Pounds. Similarly, imports in 1899 were 2.569.000 Pounds, as against 1.420.000 Points in 1900. Import volume from Great Britain dropped to $570.000^{34}$ Pounds from 1.070.000 Pounds in 1900 compared with the previous year. ${ }^{35}$

On July $7^{\text {th }}, 1990$, the governor of Aydin, Kamil Pasha, submitted a report to the Sultan Abdülhamit II about the economic condition of the city and on the decision of local health authorities on removing or relaxing of the quarantine due to no death of plague. He offered relaxing or even removing measures to be considered due to worsening economic condition of the working class and ordinary labour force to be in a limit of their endurance and starvation line. $\mathrm{He}$ also reported those workers came up to the governor's office and protested the situation. He estimated the possibility of destructive uprisings. ${ }^{36}$ After informing the current situation within the quarantine, the governor demanded financial aid from the Sultan. ${ }^{37}$ The same report informs that Christian Orthodox metropolitan visited the governorship and demanded the quarantine to be relaxed or abolished due to the demonstration of labours. ${ }^{38}$

On the other hand, the governor of Izmir, Kamil Pasha, on June $14^{\text {th }}, 1900$, reported both the health and economic condition of the city as well as the complaints and collective petition of 150 merchants and craftsmen. In his appeal to the capital, he reported a very bad agricultural and commercial condition of the

\footnotetext{
34 The same consul reported import from Great Britain as 774.000 Pounds in his correspondence in 1901. For a detailed assessment see; Parliamentary Paper, 1901, p. 709. However the difference, the consul mentioned in the report of 1900 that "Owing to the late date at which the official returns of trade are published, it is impossible to furnish a detailed account of the trade for 1900, and the total figures given...cannot be regarded as accurate. They are, however, sufficient to show how seriously the trade of Smyrna suffering..." Therefore, the import value should be corrected as 774.000 Pounds as the correct amount generated for the year 1900 and reported in the trade report of 1901. Parliamentary Paper, 1901, p. 176.

${ }^{35}$ Parliamentary Paper, 1901, p. 4, 8.

36 "İssizlikten amele güruhunun maişetçe olan ızdırâbı kesb-i şiddet ederek bu gün bunlardan birkaç yüz neferi dâire-i hükümete gelerek açlıktan feryâd etmeleriyle eğer bunlara iâne verilecek olsa yarın birkaç bin nefer birden gelip aynı halde bulunacakları şüphesiz olduğundan dâire-i belediyeye gönderilerek oradan bir suretle savuşturulmuşlardır.”, BOA, Y..EE..KP.., $12 / 1102$.

37 “...beş altı yüz lira $i$ 'tası müstarhim olunmak...” BOA, Y.EE.KP., 12/1102.

38 “...Diğer bir firka amele dahi Rum metropolid-hânesine toplanıp bağırışmaları üzerine metropolidânında nezd-i âcizime gelerek karantinanın ref'ine veya ta'diline değin bu amele fukarâsına iâne olunmazsa def'-i cu' içün her şeyi yapacaklarl derkâr olduğundan icâbına bakılması ricâ olunmuştur.” BOA, Y..EE..KP.., 12/1102.
} 
city with the merchants, the enormous cost of the decision to the state treasury, possible looting and theft in the city. He mentioned the fear and concern of merchants and wealthy community of the city on this looting and theft. He also demanded to abolish the decision of the council on established quarantine completely for not to have any death for the last 9 days. ${ }^{39}$

Meanwhile, a document dated on June $16^{\text {th }}$ informs that the central government authorised the local authorities about the allowance of 1000 Liras for the poor labour. ${ }^{40}$ The request of financial aid to the labour force was also mentioned in another archival document on June $26^{\text {th }}, 1900$, as again explaining the economic condition of the labour and requesting permission for allocation of 600 Liras from saving deposits of the governorship. ${ }^{41}$ As well as local newspaper Ahenk reported some financial aid to porters and watermen and the plan to employ them on the road construction around the city. ${ }^{42}$

Ottoman archival documents present some reactions of consuls of European countries that they demanded relaxing the quarantine and starting economic activities immediately. On July the $6^{\text {th }}, 1900$, a document reports that, on the complaints and demand of commercial community of the city, Fevzi and Hamdi Pashas, British, French, Italian and Russian consuls, together with two officials examined the condition of the epidemic. They demanded a new decision for removing or relaxing the quarantine. However, the local council did not issue a decision for relaxing the quarantine due to the need for complete disappearance of the disease. Thereupon, consuls demanded a judgement from the Sultan himself for normalizing life in Izmir and preventing more losses. ${ }^{43}$

\section{Decline of Trade}

Diplomatic correspondences show that measures taken against the plague resulted in more complications for the local and international trade than the epidemic itself. While the demographic role and impact of the presence of plague in Izmir was not severe at all, ${ }^{44}$ it had destructive economic effects. Due to the importance of Izmir for the international trade, namely exporting the agricultural products and other raw materials to Europe and importing European manufactures,

\footnotetext{
39 “....karantina tedbiri yüzünden ziraat, ticaret ve hazinenin zayiatı had ve hesapsiz olacağından, karantina yerine karantina kordonunun daha uygun olacağ l...”, BOA, Y..EE..KP.., 11/1080.

${ }^{40}$ BOA, Y..EE..KP.., 11/1081.

${ }^{41}$ BAO, Y..PRK.ASK., 162/12.

${ }^{42}$ Ahenk Gazetesi, June 23, 1900.

${ }^{43}$ BOA, Y..EE..KP.., 12/1102.

${ }^{44}$ Ottoman Archival documents show that from May 1900 until May 1901 only 24 people were reported to be with plague and only 11 of them died in the entire quarantine period. For a detailed assessment see BOA, Y..PRK.SH.., 6/49.
} 
the epidemic and measures were claimed to be hindering trade. Therefore, looking at the statistics of embarking and disembarking of cargo and other vessels, as well as their tonnage, is believed to be more accurate for the analyses of the presence of the plague of 1900 in Izmir.

The superiority of Izmir was the capacity as an important entrepot, exporting the local crop or the hinterland and distributing imports. Therefore, both annual export and import figures of Izmir before, during and after the epidemic are displayed in the table below to present the level of the effect of the plague over the trade of the region.

Table 1: Trade of Izmir, Value ( $£$, unit $)^{45}$

\begin{tabular}{|l|l|l|l|l|l|l|}
\hline Years & Export from & Import to & Total & Vessel & Tonnage & Increase \\
\hline 1895 & 4.334 .097 & 2.280 .727 & 6.614 .824 & $6224 /-$ & $1.943 .208 / 1.816 .449$ & -3166 \\
\hline 1896 & - & - & & $5929 /-$ & $1.811 .847 /-$ & - \\
\hline 1897 & - & - & & - & $-/-$ & - \\
\hline 1898 & 3.294 .529 & 2.677 .948 & 5.972 .477 & $5652 / 6044$ & $1.423 .706 / 1.985 .823$ & - \\
\hline 1899 & 3.782 .781 & 2.562 .885 & 6.345 .666 & $\ldots \ldots . / 5756$ & $-/ 2.137 .488$ & 200.000 \\
\hline 1900 & 2.541 .172 & 1.425 .480 & 3.966 .652 & $6063 / 5252$ & $2.198 .434 / 1.566 .169$ & -571319 \\
\hline 1901 & 4.348 .822 & 2.849 .304 & 7198126 & $6345 / 5806$ & $2.284 .843 / 1.908 .801$ & 342.632 \\
\hline 1902 & 4.275 .233 & 2.804 .773 & 7.080 .006 & $-/ 5509$ & $-/ 2.093 .375$ & 184.574 \\
\hline 1903 & 4.833 .931 & 2.802 .364 & 7.636 .295 & $-/ 5702$ & $-/ 2.243 .459$ & 150.084 \\
\hline 1904 & 4.754 .533 & 3.060 .000 & 7.814 .533 & $-/ 6358$ & $-/ 2.215 .204$ & -28.255 \\
\hline 1905 & 5.504 .000 & 3.214 .000 & 8.718 .000 & $-/ 5746$ & $-/ 2.340 .025$ & 124.821 \\
\hline
\end{tabular}

\footnotetext{
45 The value of number of vessels and their tons of British Consular reports do not correspond with the Ottoman numbers, taken from annuals. This might be interpreted with small Turkish coasting steamers vessels under 30 tons not being included in British reports. However, this does not explain the entire difference. Duo to this great disparity, both Turkish and British values are presented in the table. This disparity was presented also as an important concern in the trade report of the consular district of Izmir. "...the table annexed, emanating from the Ottoman Chamber of Commerce (Smyrna), can be taken as showing, at any rate approximately, the proportion of British trade to that of foreign countries. If these figures show a great disparity in comparison with those furnished sports from this Consulate from previous years, it does not necessarily mean that the general trade of Smyrna has decreased, which is far from being the case..." Parliamentary Paper, 1900, p. 4. Due to the different values of Ottoman Yearbooks and British Consular Reports, both values of vessels and tonnage were displayed on Table 1. The first value represents the Ottoman and the second one British source.
} 
Source: Salname-i Vilayet-i Aydın, 1315/1897, 1316/1898, 1320/1902, 1321/1903, 1323/1905, Parliamentary Papers, Reports for the Year 1895 on the Trade of the Smyrna Consular District, 1896, p. 12, Report for the Years 1897-99 on the Trade and Commerce of the Consular District of Smyrna, 1900, p. 4, 24, Report for the Year 1900 on the Trade of the Consular District of Smyrna, 1901, p. 9, Reports and Papers on Bubonic Plague, 1898-1901, 1902, p. 81, 85, 130,

Report for the Year 1901 on the Trade of the Consular District of Smyrna, 1902, p. 3, 8, Report for the Years 1902-03 on the Trade and Commerce of the Consular District of Smyrna, 1904, p. 11, Report for the Years 1904 on the Trade and Commerce of the Consular District of Smyrna, 1905, p. 13, Report for the Years 1905 on the Trade and Commerce of the Consular District of Smyrna, 1906, p. 10, Accounts and Papers, Annual Series Report for 1906, p. 6.

Table 1 reveals export and import volumes between 1895 and 1905 in order to make a comparison and present the effect of the epidemic over foreign trade. Export and import volume of the city presented the production and buying capacity of the whole region where Izmir was distributing centre. Analyzing the foreign trade volume shows that trade of Izmir and its region was increasing over the years. ${ }^{46}$ While foreign trade volume was on an increasing path over the years, in 1900, both imports and exports dropped considerably. Kütükoğlu (1985) calculated the import volume of the city in 40 percent less in 1900 comparing the previous year. However, it increased by 60 percent in $1901 .{ }^{47}$ According to the trade and commerce report of the consular district of the Great Britain, both imports and exports increased in 1901 and 1902 as compared with the previous year. ${ }^{48}$

The shipping trade was also disturbed by the quarantine regulations; freights were low, and the number of ships decreased. Apart from the number of vessels entering the port of Izmir, the aggregate tonnage of shipping is important. However, the number might be remaining the same or even decreasing, tonnage capacity might show the possible change. British consular reports for various years inform that there has been a gradual increase in tonnage in general and precisely German cargoes, as special arrangements with the German railway companies both in Germany and in Turkey took place. They carried commercial goods regularly and highly appreciated particularly by small traders. ${ }^{49}$

\footnotetext{
46 The buying capacity of the city was closely related to the export volume of the corresponding year and accordingly, export capacity was the determinative factor of import volume which was closely related to the agricultural expectation and abundance of the crop of the year. The prospect of local agricultural yield for the coming year was a certain concern of the British consular reports.

${ }^{47}$ Kütükoğlu, 1985, p. 119.

${ }^{48}$ Parliamentary Paper, 1904, London, p. 705.

${ }^{49}$ Parliamentary Paper, 1901, p. 18.
} 
British consular report of 1904 informs that the tonnage under the British flag remained the same ${ }^{50}$ without any fall off in the actual carrying trade of the port of Izmir. However, since the beginning of the century, there has been a notable advance in the size and carrying capacity of German, Austro-Hungarian, French, Italian and Greek vessels that they employ larger ones. Therefore, change in tonnage capacity also shows an apparent decrease during the time of quarantine and an increase in other years.

Table 2: Export and Import Volumes of Izmir with Major Partners (£)

\begin{tabular}{|c|c|c|c|c|c|c|c|c|c|c|}
\hline \multirow[t]{2}{*}{ Year } & \multicolumn{10}{|c|}{ Countries } \\
\hline & UK & & France & & Austria & & Holland & & Germany & \\
\hline & Export & Import & Export & Import & Export & Import & Export & Import & Export & Import \\
\hline 1895 & 4.334 .097 & 2.880 .727 & - & - & - & - & - & - & - & - \\
\hline 1896 & - & - & - & - & - & - & - & - & - & - \\
\hline 1897 & - & 2.251 .715 & - & - & - & - & - & - & - & - \\
\hline 1898 & 3.294 .529 & 2.677 .948 & - & - & - & - & - & - & - & - \\
\hline 1899 & 2.194 .600 & 1.071 .325 & 243.049 & 261.100 & 442.350 & 483.685 & 144.990 & 55.637 & 218.036 & 88.808 \\
\hline 1900 & 2.377 .900 & 773.763 & 284.614 & 303.620 & 433.717 & 461.710 & 224.323 & 30.140 & 210.662 & 82.008 \\
\hline 1901 & 2.475 .098 & 996.939 & 238.621 & 305.655 & 393.949 & 517.981 & 335.656 & 43.862 & 220.020 & 118.502 \\
\hline 1902 & 2.429 .886 & 979.263 & 213.621 & 306.560 & 410.859 & 530.164 & 199.373 & 35.682 & 292.408 & 138.603 \\
\hline 1903 & 2.733 .886 & 883.452 & 363.116 & 313.124 & 467.100 & 481.546 & 217.314 & 49.703 & 350.734 & 186.676 \\
\hline 1904 & 2.594 .601 & 981.815 & 275.312 & 254.643 & 503.098 & 518.763 & 276.873 & 54.531 & 297.88 & 192.715 \\
\hline 1905 & 2.625 .164 & 1.069 .368 & 244.381 & 278.834 & 754.322 & 596.508 & 434.168 & 53.615 & 414.871 & 187.716 \\
\hline
\end{tabular}

Source: Parliamentary Papers, Reports for the Year 1895 on the Trade of the Smyrna Consular District, 1896, p. 12, 13, Report for the Years 1897-99 on the Trade and Commerce of the Consular District of Smyrna, 1900, p. 9, Report for the Year 1900 on the Trade of the Consular District of Smyrna, 1901, p. 23, Reports and Papers on Bubonic Plague, 1898-1901, 1902, p. 81, 85, 130, Report for the Year 1901 on the Trade of the Consular District of Smyrna, 1902, p. 11, Report for the Years 1902-03 on the Trade and Commerce of the Consular District of Smyrna, 1904, p. 11, Report for the Years 1904 on the Trade and Commerce of the Consular District of Smyrna, 1905, p. 13, Report for the Years 1905 on the Trade and Commerce of the Consular District of Smyrna, 1906, p. 10, Accounts and Papers, Annual Series Report for 1906, p. 6.

50 "the steady annual increase in the total aggregate tonnage of all shipping visiting Smyrna was kept up in 1902 and 1903, the latter year showing a total increase of over 150.000 tons on the figures for 1902 and of more than double that amount on 1901." Parliamentary Paper, 1904, p. 710.

Similarly, the shipping returns for 1904 was reported to show a falling off of 28.255 tons. 
Table 2 focuses on five major trading partners of the Ottoman Empire, the Great Britain, France, Austria, Holland and Germany in which represented with a consul and merchants in Izmir. Both export and import decreased and sometimes this decrease is significant that actual trade volume, before and after the epidemic and quarantine fluctuated.

At this point, understanding and using British consular reports is significant that the reports generally analyse the trade of consular district in detail and report annually. They include general economic condition, export and import volume and values of the district, export and import items precisely product by product, competition, and if any treat effecting the foreign trade unfavourably as well as prospects for the coming year.

Acting Consul General of the Great Britain, Charles S. Hampson reported ${ }^{51}$ that after the epidemic and quarantine, economic activities started immediately after a long stagnation and the loss of the period tried to be covered. ${ }^{52}$ For the year 1900, there is not any unfavourable condition in the crop, rainfall, damage of harvest. The only extraordinary condition is reported to be the epidemic and quarantine measures followed after it. Moreover, the prospect for the year 1900 was so favourable. "...the winter having been mind, with plenty of rain, though the effects on local agriculture of a most disastrous earthquake in September, 1899, might have been considerable, had it not been for the namely relief of the sufferers, in furnishing which British charity largely participated. Moreover, an important immigration of agriculturists from Crete has more than replaced the list of life occasioned by the earthquake." ${ }^{53}$

The export capacity of Izmir depended almost entirely on the agricultural crops from the interior cities such as Aydin, Denizli, Manisa. Addition to the consular report of reporting any extraordinary condition damaging or affecting the crop badly, analysing if there has been a drop in any of the agricultural items for the particular period is essential.

\footnotetext{
${ }^{51}$ Like the Parliamentary papers, consul describes the general downsizing of all economic activities, increased unemployment, certain drop and disorder in shipping activities, considerably drop in export and import until September 1900. The National Archives, Foreign Office Papers (FO), $78 / 5135,1901$.

${ }^{52} \mathrm{FO}, 78 / 5135,1901$.

${ }^{53}$ Parliamentary Paper, 1900, p. 4.
} 


\section{Emine ZEYTINLI}

Table 3: Trade of Main Export Items of Izmir

\begin{tabular}{|c|c|c|c|c|c|}
\hline $\begin{array}{l}\text { Export } \\
\text { Product }\end{array}$ & $\begin{array}{l}\text { Export from } \\
\text { Izmir, Years }\end{array}$ & Value in $£$ & Import Products & $\begin{array}{l}\text { Import to } \\
\text { Izmir, years }\end{array}$ & Value in $£$ \\
\hline & 1899 & 1.048 .406 & & 1899 & 1.197 .147 \\
\hline \multirow[t]{3}{*}{ Raisin } & 1900 & 516.468 & $\begin{array}{l}\text { Manufactures; textiles } \\
\text { and yarns }\end{array}$ & 1900 & 885.364 \\
\hline & 1901 & 761.906 & & 1901 & 1.324 .133 \\
\hline & 1899 & 441.131 & & 1899 & 431.325 \\
\hline \multirow[t]{3}{*}{ Valonea } & 1900 & 427.473 & Agricultural products & 1900 & 493.835 \\
\hline & 1901 & 379.826 & & 1901 & 532.514 \\
\hline & 1899 & 341.357 & & & \\
\hline \multirow[t]{3}{*}{ Fig } & 1900 & 365.102 & & & \\
\hline & 1901 & 387.624 & & & \\
\hline & 1899 & 340.512 & & & \\
\hline \multirow[t]{3}{*}{ Barley } & 1900 & 839.716 & & & \\
\hline & 1901 & 696.593 & & & \\
\hline & 1899 & 332.662 & & & \\
\hline \multirow[t]{3}{*}{ Opium } & 1900 & 285.568 & & & \\
\hline & 1901 & 300.478 & & & \\
\hline & 1899 & 301.05 & & & \\
\hline \multirow[t]{3}{*}{ Carpet } & 1900 & 292.967 & & & \\
\hline & 1901 & 284.157 & & & \\
\hline & 1899 & 140.291 & & & \\
\hline \multirow[t]{3}{*}{ Tobacco } & 1900 & 168.911 & & & \\
\hline & 1901 & 205.885 & & & \\
\hline & 1899 & 154.266 & & & \\
\hline \multirow[t]{2}{*}{ Cotton } & 1900 & 347.189 & & & \\
\hline & 1901 & 238.808 & & & \\
\hline
\end{tabular}


Plague of 1900 and the Economic Effect on the Overseas Commerce of Izmir

\begin{tabular}{|l|l|l|l|l|l|}
\hline & 1899 & 691.927 & & & \\
\hline Others & 1900 & 816.131 & & & \\
\hline & 1901 & & & & \\
\hline
\end{tabular}

Source: Parliamentary Papers, Reports for the Year 1895 on the Trade of the Smyrna Consular District, 1896, p. 12, 13, Report for the Years 1897-99 on the Trade and Commerce of the Consular District of Smyrna, 1900, p. 20, Report for the Year 1900 on the Trade of the Consular District of Smyrna, 1901, pp. 4-7, Reports and Papers on Bubonic Plague, 1898-1901, 1902, p. 85, 130, Report for the Year 1901 on the Trade of the Consular District of Smyrna, 1902, p. 6.

Table 3 above displays the agricultural commodities as export products as well as import items of the region with their share in corresponding years of 1899 , 1900 and 1901. Commercial products of Izmir are raisin, valonea, fig, barley, opium, carpet, tobacco and cotton. The capacity of export of Izmir consisted of its hinterland namely from the provinces of Aydin, Denizli, Manisa, and Usak. Therefore, interruption of interior transport of commercial products and crops affected the trade capacity of Izmir negatively or positively in this particular year. Export volume of raisin decreased almost half due to the plague epidemic and harvest time coincided the same period. Export of valonea and opium showed a similar feature. The most important export item of Izmir was fig and did not show any drop but a slight increase since the epidemic ended before the harvest time. Barley and cotton export increased more than double due to the harvest time and durability of the products.

\section{Conclusion}

Plague had been one of the most destructive and infectious disease in the history with severe social, demographic and economic effects. The continental Europe heavily experienced the plague epidemics since the medieval times until the twentieth century. It severely affected economic development and demographics of the countries. Production volumes declined, commerce was disrupted, due to scarcity of labor wages increased, the nature of employment changed. People fled their cities and economic and social structure of cities changed.

Port cities were exposed to the epidemics due to intensive interaction of local population and foreigners, goods and especially rats-which carry illnesses themselves-carried by trading ships and foreigners. Izmir was one of those cities; its location and being an important commercial hub made it the main shipping routes of the Levant trade as well as brought epidemics carried by seamen and passengers. 
In 1900, only 11 people died because of the plague in Izmir. The quarantine against the plague lasted three months and resulted severe economic losses for both domestic and foreign merchants. The city and the whole region experienced declines in domestic and international trade during the quarantine measures that prevented the entry of commercial vessels to the port. After examining the Ottoman archival documents and consular reports of the period, it appears that the economic impact of the quarantine was much greater than the demographic effects of the plague. The quarantine against the plague began to be applied in May and was eased up by the beginning of September of the same year.

The foreign and domestic traders blamed Ottoman central government and local authorities for taking disproportionate quarantine measures against the epidemic despite the low number of deaths and non-progress of the epidemic. Some of the official reports in archival documents explain that local health authorities and doctors used the quarantine for their benefits, but merchants were also against it for their own benefits. In order to protect their trade, the merchants tried to hide the existence of the epidemic and the number of deaths.

The official correspondence of Ottoman authorities, the commercial statistics on export and import volumes in Izmir reveals that the plague and quarantine against it caused huge damage on the trade of Izmir. Maritime activities interrupted, flow of goods stopped, export and import volumes decreased, unemployment increased. It created much dissatisfaction among local and foreign tradesmen, labour and other segments of the society. Unemployment increased and led to some social disorders and some forms of uprising in the city even though it lasted only three months, until the beginning of September of the same year. 


\section{BIBLIOGRAPHY}

\section{a. Archival Documents}

State Archives of Turkey (BOA)

Dahiliye Nezareti, Mektubi Kalemi (DH.MKT.), 2345/73.

Sadaret Defterleri, Mektubi Kalemi, Mühimme Kalemi Evrakı, (A.MKT.MHM.), 566/16. Yıldız Sadrazam Kamil Paşa Evrakı, (Y..EE..KP..), 10/1070, 11/1038, 11/1039, 11/1078, 11/1079, 11/1080, 11/1081, 12/1102.

Y1ldız Perakende Evrak1, Askeri Maruzat (Y..PRK.ASK.), 162/12.

Yildız Hususi Maruzat (Y..A...HUS.), 409/98.

Yıldız Perakende Evrakı, Sıhhiye Nezareti Maruzatı (Y..PRK.SH), 6/49

\section{Ottoman Yearbooks (Salname)}

Salnâme-i Vilayet-i Aydın, (H.1315)/1897, Aydın Vilayet Matbaası, Aydın, 1897. (H.13169/1898, Aydın Vilayet Matbaası, Aydın, 1898.

(H.1320)/1902, Aydın Vilayet Matbaası, Aydın, 1902.

(H.1321)/1903, Aydın Vilayet Matbaası, Aydın, 1903.

(H.1323)/1905, Aydın Vilayet Matbaası, Aydın, 1905.

\section{The National Archives and Parliamentary Papers of the Great Britain}

Foreign Office Papers, 78/5135, 1901.

Parliamentary Papers, Reports for the Year 1895 on the Trade of the Smyrna Consular

District, Annual Series, No. 1784, Harrison and Sons, London, 1896.

Report for the Years 1897-99 on the Trade and Commerce of the Consular District of

Smyrna, Annual Series, No. 2462, Harrison and Sons, London, 1900.

Report for the Year 1900 on the Trade of the Consular District of Smyrna, Annual Series,

No. 2641, Harrison and Sons, London, 1901.

Reports and Papers on Bubonic Plague, 1898-1901, Darling and Son Ltd., London, 1902.

Report for the Year 1901 on the Trade of the Consular District of Smyrna, Annual Series,

No. 2854, Harrison and Sons, London, 1902.

Report for the Years 1902-03 on the Trade and Commerce of the Consular District of Smyrna, Annual Series, No. 3170, Harrison and Sons, London, 1904.

Report for the Years 1904 on the Trade and Commerce of the Consular District of Smyrna, Annual Series, No. 3467, Harrison and Sons, London, 1905.

Report for the Years 1905 on the Trade and Commerce of the Consular District of Smyrna, Annual Series, No. 3722, Harrison and Sons, London, 1906.

Accounts and Papers, Annual Series Report for 1906, Volume 116, London, 1908.

Accounts and Papers, Annual Series Report for 1909, Volume 103, London, 1910. 


\section{Emine ZEYTINLI}

\section{Newspapers}

Ahenk Gazetesi, May 4, May 7, June 14, June 23, 1900.

\section{b. Published Sources}

Beyru 2005 Rauf Beyru, 19. Yüzyllda İzmir'de Sağllk Sorunlarl ve Yaşam, İzmir Büyükşehir Belediyesi Kültür Yayını.

Bulmuş 2012 Birsen Bulmuş, Plague, Quarantines and Geopolitics in the Ottoman Empire. Edinburgh.

Dallaway $1797 \quad$ James Dallaway, Constantinople Ancient and Modern: with Excursions to the Shores and Isşands of the Archipelago and to the Troad, Printed by T. Bensley, London.

Echenberg $2010 \quad$ Myron Echenberg, Plague Ports: The Global Urban Impact of Bubonic Plague 1894-1901, New York University Press.

Fuller 1829 John Fuller, Narrative of a Tour through Some Parts of the Turkish Empire, Richard Taylor, London.

Hamlin 1977 Cyrus Hamlin, Among the Turks, American Tract Society, New York.

Issawi 1980 Charles Issawi, The Economic History of Turkey: 1800-1914, Publication of the Center for Middle Eastern Studies, No. 13, University of Chicago Press, Chicago, London.

İmir Ticaret Odası 1986

Türkiye Ekonomisinin 100. Yll ve İzmir ve İzmir Ticaret Odası Sempozyumu: 1885-1985, İzmir Ticaret Odas1, İzmir.

Kalisch 1972

Philip A. Kalisch, The Black Death in Chinatown: Plague and Politics in San Francisco 1900-1904, Arizona and the West, Vol. 14, No. 2, pp. 113-136.

Kasaba 1988

Resat Kasaba, The Ottoman Empire and the World Economy, The Nineteenth Century, Sunny Press.

Kütükoğlu 1985 Mübahat S. Kütükoğlu, “Osmanlı Dış Ticaretinin Gelişmesinde İzmir Limanı ve Gümrüklerin Rolü, 1885-1985", Türkiye Ekonomisinin 100. Yll ve İmir Ticaret Odası Sempozyumu: 1885-1985, İzmir Ticaret Odası Yayınları, İzmir.

Landau 1985 Paul Landau, “1900’lerde İzmir”, Türk Dünyası Araştırmaları Dergisi, Translated by Sükrü Ünlü, Number 38, pp. 148-181.

McKeough 2018 Michelle McKeough, "Caught in an International Crisis: How Fremantle Fell Victim to Bubonic Plague 1900-1906", Australian Association for Maritime History, Vol. 40, No. 1, pp. $1-19$.

Mithat 1902

Ahmed Mithat, "Devlet-i Aliyye-i Osmaniye'de Karantina Yani Usul-i Tahaffuzun Tarihcesi" Salname-i Nezareti-i Umur-i Hariciye, Matbaa-i Osmaniye, Vol. III, İstanbul.

Panzac 2017 Daniel Panzac, Osmanlı Imparatorluğu'nda Veba, Tarih Vakfı Yurt Yayınları, İstanbul. 
Shakow 2009

Aaron David Abraham Shakow, Marks of Contagion: The Plague, the Bourse, the Word and the Law in the Early Modern Mediterranean, 1720-1762, Harvard University.

The British Medical Journal, 1990

"Plague and Plague Measures in the Turkish Empire", Vol. 2, No. 2086, 1900, pp. 1810-1811.

Varlık 2015

Nükhet Varlık, Plague and Empire in the Early Modern Mediterranean World: The Ottoman Experience, 1347-1600, Cambridge University Press.

White 2010 Sam White, Rethinking Disease in Ottoman History, International Journal of Middle East Studies, Vol. 42, No. 4, pp. 549-567.

Zavitziano $1900 \quad$ Spiridion C. Zavitziano, "Report from Constantinople", Public Health Reports (1896-1970), Vol. 15, No. 33, Report No 249.

Zavitziano 1900 Spiridion C. Zavitziano, "Examination of Plague Case at Smyrna-Spread of Plague on Turco-Persian Frontier", Public Health Reports (1896-1970), Vol. 15, No. 25, Report No 246, 1900. 